\title{
Perception of Trainers for The Athlete
}

\section{Serkan KURTIPEK ${ }^{1}$, NURİ BERK GÜNGÖR ${ }^{1}$}

${ }^{1}$ Gazi University Faculty of Sport Sciences, Ankara

Address Correspondence to NB, Güngör e-mail: nuriberkgungor@gmail.com

\begin{abstract}
The aim of this research is to determine the perceptions of the trainers in different sports branches on the athletes through metaphors. The sample of study consists of 72 trainers in different sports branches. For the collection of data in the study, "metaphor form" was prepared to determine the participants' views on the concept of athletes. In the metaphor form, the athletes were asked to complete the sentence of "Athlete is like...; Because ..." In this study, phenomenological design from qualitative research approaches is used. In the analysis of the data, content analysis technique was used. For the reliability of the analysis of the research data, the reliability coefficient was calculated between the participants and this value was found to be $93 \%$. With the evaluation of the data, it was seen that the sports club members produced 32 metaphors. These metaphors were collected in 4 different categories. While the trainers were determined to develop metaphors most in the category of "openness to development" and "value" for the concept of athlete, these categories were followed by categories of "responsibility" and "being hardworking". The most produced metaphors of the trainers are diamond, baby, sapling, bee, rough mine and gold. Trainers often used live and tangible metaphors for the concept of athlete. Considering the data obtained, the participants pointed to the basic characteristics that should be in the ideal athlete. These characteristics represent a structure that has the capacity to develop and has a value and a sense of responsibility.
\end{abstract}

Keywords: Sports, Athlete, Trainer, Metaphor, Qualitative Research Method.

\section{INTRODUCTION}

Sport is the intense efforts to improve the physical and mental health of the individual, to fight within the dimensions of competition according to certain rules, to be excited, to be competitive, to be superior and to increase the power of success in the real sense and to increase it to the highest level in a personal sense(1). However, although it is carried out for many different purposes such as competition, pleasure, health, aesthetics, entertainment, game, advertising, propaganda, profession, science, leisure time, it is also important in terms of organizing personal and social relations. The basic element of sport is human. Therefore, it has become an indispensable social phenomenon in terms of whether it is to create a society with high productivity or to raise the young, creative and healthy youth of the future or to be a tool that can resist social segregation and alienation (2).

Nowadays, while increasing the sphere of influence on human life, sports is becoming more and more important in terms of place and importance in society. People who do sports in an individual sense develop in terms of physical and mental abilities. It is known that it strengthens the interpersonal social ties and socializes the individual in terms of its social aspect (3). It is possible to say that sportive activities contribute to the multifaceted development of individuals. In particular, it is evident that it contributes to the development of personality structure of the individual, improves physical and mental health and contributes to display positive behaviors $(4,5,6)$. Increased interest in physical activity and sport in recent years can be related to the positive contributions of sports to both body and mental health of the individual (7).

This growing interest in physical activity and sport has drawn attention to the importance of trainers who has the role of being an educator. It is because the trainer is an exemplary teacher for athletes, the person who demonstrates the good direction of influence on the team. At the same time, in addition to being a sociological person who implements effectively the training programs, which is prepared for the long run, to carry the athletes to success, and teaches athletes the life while implemeting the program, and $\mathrm{s} / \mathrm{he}$ is also a person who is looking for new ways and methods to sustain the development of sports and athletes $(8,9)$. In 
short, trainers are important keystones in the development of sports and athletes. It is surely beyond doubt that for the trainers, the athletes are like a mine to be processed. There are many acquisitions that a good trainer can offer to the athlete and/or athletes. After a certain point, this process acquires a mutually continuity. For this reason, the point of view of trainers to athletes is important for opening a correct communication channel.

In the research, metaphors were produced in order to provide a different perspective on the concept of "athletes". Metaphor is an analogy that defines an object by imagination with the help of another object (10).

When the literature is examined, it is observed that metaphors related to many concepts are

\section{MATERIALS \& METHODS}

In this study, phenomenological design, one of the qualitative research methods, was selected. The sample of this study conducted in 2019 consists of 72 trainers working in different sports branches (tennis, gymnastics, basketball) in Ankara. The study group was selected through criterion sampling method according to purposeful sampling method. In this context, the criteria such as the fact that the trainers are still working and willing to participate voluntarily were taken into consideration.

In this study, data were collected with semistructured interview form which is used very frequently in metaphor studies $(17,18,19)$. At this point, the trainers were asked to indicate and explain a metaphor describing the athlete. The trainers were asked to complete the sentence of "Athlete is like...; Because..." and as a result, it was determined that only one metaphor was specified by the participants and the explanations of these metaphors were made.

Data analysis is the process of exporting the meaning of data. In other words, it consists of statements of the participants and the combination and interpretation of what the researchers has seen and read (20). Therefore, in the data analysis of this study, numbers from 1 to 72 were first given to papers. Data were analyzed by content analysis method. Content analysis is the categorization of data (21). Content analysis was carried out in 8 stages. These are (1) examination of forms and elimination of inappropriate forms, recompilation of forms, (3) numbering forms (4) produced $(11,12,13)$. However, while the number of studies examining the metaphors related to the concept of sports is limited $(14,15,16)$, there is no research about the metaphors related to the concept of athlete. In these studies carried out with different sample groups, sports and sports branch concepts were examined through metaphors. However, a research conducted on the concept of athletes and trainers who have a very important role in the sport is not present in the literature. In this context, the aim of the research is to express the concept of athlete from the point of view of the trainers. For this reason, the research is important in order to fill the gap in the relevant field literature, to determine the opinions of the stakeholders involved in sports for the concept of athlete and to enable the trainers to express their opinions about the concept of athletes in a detailed manner.

examination of metaphors, (5) development of categories, (6) the stage of providing validity and reliability, (7) calculation of frequencies of obtained metaphors, and (8) interpretation of metaphors $(22,23,24)$.

In the first stage, the trainers' expressions were investigated and whether there were any blank parts or not was examined in general and there was no form with missing part. In the second stage, the metaphors in the forms were listed and tabulated. In the third stage, the numbering from P1 to P72 was made after organizing the metaphors according to their frequency. In the fourth stage, the metaphors were re-examined. In the fifth stage, the metaphors for the concept of athlete were examined in terms of their common features. As the metaphors stated by the trainers were emphasized in a way that they could be included in several categories at the same time, the metaphors were placed in the relevant categories according to the trainers' statements.

The sixth stage is about the reliability and validity. In this stage, the process of analyzing the data obtained from the trainers and how the codes associated with the categories were directly presented to the reader with the trainers' statements. In the research, samples of trainer views were selected and included in the findings section (25). In order to ensure the reliability of the study, data were analyzed by 3 field experts and the results of the analysis were compared. In the reliability of data analysis, the formula developed by Miles and Huberman in 1994 was used. A total of 32 
metaphors were produced and on 2 metaphors (machine, work) there were a dissensus. The mean reliability of the encoders was found to be 93\% [30/ $(30+2) \times 100=93 \%$. According to these results, the research has the desired reliability level (26).
In the 7 th stage, the distribution and frequency of metaphors developed by the trainers were calculated and the findings obtained were interpreted in the last stage.

\section{FINDINGS}

This section includes the metaphors of the participants working as a trainer in different sports branches, the categories and explanation examples.

\begin{tabular}{|c|c|c|c|c|c|}
\hline $\begin{array}{c}\text { Metaphor } \\
\text { Order }\end{array}$ & Metaphor Name & $\mathbf{f}$ & $\begin{array}{c}\text { Metaphor } \\
\text { Order }\end{array}$ & Metaphor Name & f \\
\hline 1 & Diamond & 9 & 18 & Child & 1 \\
\hline 2 & Baby & 6 & 19 & Raw materials & 1 \\
\hline 3 & Sapling & 5 & 20 & Statue & 1 \\
\hline 4 & Bee & 5 & 21 & Dough & 1 \\
\hline 5 & Rough Mine & 4 & 22 & Structure & 1 \\
\hline 6 & Gold & 4 & 23 & Iron & 1 \\
\hline 7 & Seed & 3 & 24 & Work & 1 \\
\hline 8 & Ant & 3 & 25 & Ore & 1 \\
\hline 9 & Tree & 3 & 26 & Aged Wine & 1 \\
\hline 10 & Garden & 3 & 27 & Private Individual & 1 \\
\hline 11 & Plant & 2 & 28 & Father & 1 \\
\hline 12 & Coal & 2 & 29 & Waiter & 1 \\
\hline 13 & Treasure & 2 & 30 & $\begin{array}{c}\text { Lion } \\
\end{array}$ & 1 \\
\hline 14 & Staff & 2 & 31 & Responsible Individual & 1 \\
\hline 15 & Manager & 2 & 32 & Machine & 1 \\
\hline 16 & Parrot & 1 & & & \\
\hline 17 & Paper & 1 & & TOTAL OPION & 72 \\
\hline
\end{tabular}

When Table 1 is examined, it is seen that the trainers produced 32 different metaphors for the concept of "athlete" and stated 72 opinions for this. Diamond (32), Baby 68), Sapling (5), Bee (5), Rough mine (4) and Gold (4) metaphors were the most stated metaphors. It is thought that according to frequencies, most of the metaphors are towards the fact that athletes are the individuals who are open to innovation and development. When the metaphors developed by the trainers in relation to the athlete concept are evaluated together with their explanations, the classification as four categories is shown in Table 2.

Table 2: Distribution of Metaphors Developed by Trainers according to Categories

\begin{tabular}{lcc}
\hline Categories & Number of Metaphor (f) & $\%$ \\
\hline 1. Openness to Development & 16 & 50,00 \\
\hline 2. Value & 7 & 21,87 \\
\hline 3. Responsibility & 6 & 18,75 \\
\hline 4. Being Hardworking & 3 & 9,37 \\
\hline TOTAL & 32 & 100.0 \\
\hline
\end{tabular}

According to Table 2, trainers indicated the metaphors under four categories for the concept of athletes. These categories are openness to development (16-50.00\%), value (7- 21.87\%), responsibility (6\% 18.75) and being hardworking (3\% 9.37\%). 
Table 3: Metaphors of the Category of "Openness to Development" and Explanations

\section{Category}

1. Openness to Development

\section{Number of Metaphor $(\mathrm{f}=16)$}

Baby (6), Sapling (5), Rough mine (4), Garden (3), Tree (3), Seed (3), Plant (2), Coal (2), Parrot

(1), Paper (1), Raw Material (1), Statue (1), Dough (1), Structure (1), Iron (1), Child (1)

Quotations from the description examples of trainers;

Baby; The athlete grows in the hands of a trainer, and if the trainer begins training the athlete from an early age, he keeps the athlete's technique, thoughts and all life in his hands (P20).

Sapling; When it is in the hands of a gardener who knows how to grows it well, it becomes a century-old tree (P23).

Rough mine; Its value increases as it is processed (P35).

Seed; You plant the seed in the field, you water it, you grow it and you get a product. You reach many people with your product (P18).

Parrot; The more his owner is interested in it, the more words it learns (P2).

When the total of 16 metaphors and explanations stated in the "openness to development" category in Table 3 are examined, it is understood that the participants stated that the trainers are an important element in training the successful athletes, emphasizing the aspects of the athletes that are open to continuous development.

Table 4: Metaphors of the Category of "Value" and Explanations

\begin{tabular}{lc}
\hline Category & Number of Metaphor (f=7) \\
\hline 2. Value & Diamond (9), Gold (4), Treasure (2), Ore (1), Aged Wine (1), Work (1), Private \\
Individual (1)
\end{tabular}

Quotations from the description examples of trainers;

Diamond; It is very valuable (P37).

Gold; It never loses value (P44).

Aged wine; Over the years, its value increases (P47).

Treasure; It is sought everywhere but it is revealed difficultly (P55).

As shown in Table 4, a total of 7 metaphors are mentioned in the "value" category for the athlete concept. As stated in the explanations, it is understood that participants developed metaphors for athletes' characteristics of being a privileged and valuable individual.

Table 5: Metaphors of the Category of "Responsibility" and Explanations

\begin{tabular}{l} 
Category \\
\hline 3. Responsibility \\
Quotations from the description examples of trainers; \\
Manager; Just as the manager has responsibilities to the organization and its employees, the athlete has responsibilities towards \\
himself, his family, his trainers and the community (P61). \\
Personnel; S/he has responsibilities for the workplace where he works (P57). \\
Father; He sacrifices his own life and is responsible to his family and children. This is the case for the athlete (P56). \\
Lion; He has responsibilities for protecting his/her living space and is aware of this (P62).
\end{tabular}

As shown in Table 5, a total of 6 metaphors are mentioned in the category of "responsibility" for the concept of athletes. As stated in the statements, it is understood that the participants emphasize that the athletes are responsible especially to themselves and also their families, their trainers and even society.

Table 6: Metaphors of the Category of "Being Hardworking" and Explanations

\begin{tabular}{ll}
\hline Category & Number of Metaphor (f=3) \\
\hline 4.Being Hardworking & Bee (5), Ant (3), Machine (1), \\
\hline
\end{tabular}

Quotations from the description examples of trainers ;

Ar1; While working, it makes honey and produces something (K64), it is hardworking and does its works day to day (P65).

Ant; It works for something constantly until it dies (P69).

Machine; Athletes are also working like machine (P72). 
As shown in Table 6, a total of 3 metaphors are mentioned in the category of "being hardworking" regarding the concept of athletes. As it is understood from the explanations, it is understood that the participants emphasized the athletes' characteristics of being hardworking by likening them to bees and ants which are the most hardworking animals.

\section{DISCUSSION \& CONCLUSION}

In this study, it was aimed to determine the emotions and thoughts of the participants, who are training in different branches, by means of analogy. According to the data obtained, the perceptions of the participants about the concept of athlete were interpreted.

It was concluded that participants produced a total of 32 metaphors related to the concept of athletes. These are the categories of openness to development, value, responsibility and being hardworking. A total of 16 metaphors were identified in the category of "openness to development". From the statements, such as: He is like a Sapling, when it is in the hands of a gardener who knows how to grows it well, it becomes a century-old tree, it is like a Rough mine, its value increases as it is processed, it is like a Seed, you plant the seed in the field, you water it, you grow it and you get a product. You reach many people with your product, it is seen that how important the trainer is in the career development of an athlete. The trainer is the person who tries to make the athlete work in unity and solidarity within the team ${ }^{27}$. S/he takes on the role of a craftsman for the development of the athlete. S/he plans and works in order to bring the athlete step-by-step to the targeted level within a certain process. The athlete is aware of this process and walks on the same path with his trainer to achieve his goal. The process is focused on process development through this communication channel maintaining mutually. In this context, it can be stated that trainers are an important building block when considering the development of athletes. When the studies carried out in the near disciplines are examined, it is seen that metaphors are produced under the theme of openness to development in the studies in which there are facts similar to the trainer and athlete relationship. In their study, with the theme of informative and formative teacher ${ }^{28}$, Yılmaz, Esentürk, Tekkurşun-Demir \& İlhan (2017) with the development provider theme ${ }^{29}$, Demirtaş \& Çoban (2014) with the theme of changing/ developing instructors emphasized that the participants produced metaphors about the fact of openness to development and stressed the importance of development in the educational process $^{30}$.

It is seen that participants produced 7 metaphors in the "value" category for the athlete concept. These metaphors formed the relevant category with the statements such as; It is like a diamond, it is very valuable, it is like Gold, it never loses its value, it is like the aged wine, its value increases over the years, it is like the treasure, it is sought everywhere, but it is revealed difficultly. From the analogies of valuable ores for the concept of athlete, it can be stated that the concept of athlete is a valuable fact for the trainers. In the literature, Demirtaş \& Çoban (2014) determined also in their studies that the participants produced metaphors such as Flower Garden, Angel, Mevlana and Daffodil under the theme of value ${ }^{30}$. Another category that emerged according to the research results is the category of "responsibility". A total of 6 metaphors were produced in this category. Statements for the metaphors in the relevant category, such as; s/he is like Manager, just as the manager has responsibilities to the organization and its employees, the athlete has responsibilities towards himself, his family, his trainers and the community, s/he is like a Personnel, s/he has responsibilities for the workplace where he works, s/he is like a father, he sacrifices his own life and is responsible to his family and children, s/he is like a Lion, he has responsibilities for protecting his/her living space and is aware of this, reveal the necessity of the acquisition of responsibility among the characteristics of the athletes as a duty when the athletes are evaluated with the point of view of the trainers..

The last category that the participants produced for the athlete concept is the category of "hardworking" and a total of 3 metaphors were produced. With metaphors, there are statements such as; S/he is like a bee, it makes honey while working, produces something, s/he is like an ant, s/he works for something continuously until its death, s/he is like a machine, athletes work constantly like a machine. When the metaphors produced by the participants in the relevant category were examined, it was revealed that the athletes should have a characteristic such as being hardworking. This is because the athlete must achieve a continuous rhythm of work in order to achieve a determined career goal. Otherwise, the temporary achievements will remain in the shadow of the targets. It is important for the trainers to draw attention to this issue in order for athletes to 
determine the parameters to be taken into consideration while aiming their own development. However, in the summer of the field, determined that the theme of being hardworking were revealed among the metaphors produced, and that being hardworking was important when dealing with a parameter related to the educational process ${ }^{31,32}$.

As a result, trainers tried to express the concept of athletes with a different perspective through the metaphors they produced. Considering the data obtained, the participants pointed to the basic characteristics that should be in the ideal athlete. These characteristics represent a structure that has the capacity to develop and has a value and a sense of responsibility. It is possible to say that the characteristics stated are the acquisitions that each trainer demands from the athlete to have. In this context, the research described the characteristics, which the ideal athlete should have, with the point of view of the trainers. In addition, the most striking descriptions of the coaches for the concept of athletes were in the development parameter. They defined the concept of athlete as a phenomenon that developed through an accurate training process. However, in the studies to be carried out, it is recommended to plan metaphor studies for the concept of athlete from the point of view of all the stakeholders involved in the sport.

\section{REFERENCES}

1. Kılıçaslan U. Spor lisesi ile diğer liselerde öğrenim gören öğrencilerin bazı motorik özelliklerinin karşılaştırılması: Trabzon ili örneği. Yüksek Lisans Tezi, Karadeniz Teknik Üniversitesi Eğitim Bilimleri Enstitüsü, 2015; Trabzon.

2. Yetim A. Sosyoloji ve spor, 2011; Ankara: Berikan Yayınevi.

3. Ekmekçi R, Ekmekçi Dağlı Y. A.Sports marketing. Pamukkale Journal of Sport Sciences, 2010; 1(1): 23-29.

4. Akandere $M$, Özyalvaç N, Duman S. Ortaöğretim öğrencilerinin beden eğitimi dersine yönelik tutumları ile akademik başarı motivasyonlarının incelenmesi (Konya Anadolu Lisesi Örneği) Selçuk Üniversitesi Sosyal Bilimler Enstitüsü Dergisi, 2010; 24: 1-10.

5. Caterino MC, Polak ED. Effects of two types of activity on the performance of second-, third-, and fourth-grade students on a test of concentration. Percept Mot Skills. 1999; 89: 245-248.

6. Büyükyazı G, Saraçoğlu SA, Karadeniz G, Çamlıyer H, Çamliyer H. Sedanterler ile veteran atletlerin çeşitli değişkenlere göre atılganlık düzeylerinin karşılaştırılması. Gazi Beden Eğitimi Spor Bilimleri Dergisi, 2013; 8(4): 13-24.

7. Akça NŞ. Özel spor merkezlerine üye olan bireylerin spora yönelme nedenleri ve beklentilerinin gerçekleşme düzeyleri. Yüksek Lisans Tezi, Ankara Üniversitesi Sağlık Bilimleri Enstitüsü, 2012; Ankara.

8. Acet M. Futbol seyircisini fanatik ve saldırgan olmaya yönelten sosyal faktörler. Doktora Tezi, Gazi Üniversitesi Sağllk Bilimleri Enstitüsü, 2011; Ankara.

9. Donuk B. Türkiye profesyonel futbol ligleri antrenörlerinin liderlik tarzlarının incelenmesi ve bir model yaklaşım.
Doktora Tezi, Marmara Üniversitesi Sağlı Bilimleri Enstitüsü Beden Eğitimi ve Spor Anabilim Dalı, 2006; İstanbul.

10. Thomas L, Beauchamp C. Understanding new teachers' professional 1dentities through metaphor. Teaching and Teacher Education, 2011; 27, 762-769.

11. Namlı A, Temel C, Güllü M. Ortaokul öğrencilerinin beden eğitimi dersine ilişkin ürettikleri metaforlar. Kastamonu Eğitim Dergisi, 2017; 25(2), 479-496.

12. Karaca SY, Ada S. Öğrencilerin matematik dersine ve matematik öğretmenine yönelik algılarının metaforlar yardımıyla belirlenmesi. Kastamonu Eğitim Dergisi, 2018; 26(3), 789-800.

13. Tiryaki EN, Demir A. Türkçe öğretmeni adaylarının yazma becerilerine yönelik metaforik algıları. Mustafa Kemal Üniversitesi Sosyal Bilimler Enstitüsü Dergisi, 2016; 13(33), 110.

14. Sevinç ÖS, Ergenç M. Düzce Üniversitesi'nin bazı fakültelerinde öğrenim görmekte olan lisans öğrencilerinin "spor" hakkındaki metaforları. Düzce üniversitesi Sosyal Bilimler Enstitüsü Dergisi, 2017; 7(2), 106-131.

15. Karakaya ED, Salici, O. Isparta'da öğrenim gören 11-13 yaş gurubu öğrencilerin popüler spor branşları hakkındaki metaforik algilarının belirlenmesi. International Journal of Social Sciences and Education Research, 2016; 2(3),1059-1076.

16. Koç M, Murathan F, Yetiş Ü, Murathan T. İlköğretim 7. sınıf öğrencilerinin spor kavramına ilişkin algıları, Akademik Sosyal Araştırmalar Dergisi, 2015; 3(9), 294-303.

17. Döş İ. Aday öğretmenlerin müfettişlik kavramına ilişkin metafor algıları. Gaziantep Üniversitesi Sosyal Bilimler Dergisi, 2010; 9(3), 607-629.

18. Inbar $\mathrm{D}$. The free educational prison: Metaphors and images. Educational Research, 1996; 38 (1), 77-92.

19. Saban A. Öğretmen adaylarının öğrenci kavramına ilişkin sahip oldukları zihinsel imgeler. Türk Eğitim Bilimleri Dergisi, 2009; 7(2), 281-326.

20. Merriam SB.Nitel araştırma desen ve uygulama için bir rehber (3. bs.)[Qualitative research a guide to design and implementation ](Selahattin Turan, trans.). 2015; Ankara: Nobel Yayıncilık.

21. Patton MQ. Nitel Araştırma ve Değerlendirme Yöntemleri. 3. Baskıdan Çeviri (Çev Edit; Bütün, M \& Demir, S. B.) 2014; Ankara. Pagem Akademi.

22. Ekici G. Biyoloji öğretmeni adaylarının mikroskop kavramına ilişkin algılarının belirlenmesi: Bir metafor analizi çalışması. Ahi Evran Üniversitesi Kırşehir Eğitim Fakültesi Dergisi, 2016; 17(1), 615-636.

23. Ekici G, Gökmen A, Kurt H. Öğretmen adaylarının "bilgisayar" kavramı konusundaki bilişsel yapılarının belirlenmesi. Gazi Üniversitesi Gazi Eğitim Fakültesi Dergisi, 2014; 34(3), 359-405.

24. Saban A. Okula ilişkin metaforlar. Kuram ve Uygulamada Eğitim Yönetimi, 2008; 55, 459-496.

25. Yıldırım A, Şimşek H. Sosyal Bilimlerde Nitel Araştırma Yöntemleri (Genişletilmiş 9. Baskı). 2014; Ankara: Seçkin Yayınları.

26. Miles MB, Huberman AM. Qualitative data analysis: An expanded sourcebook. 1994; Sage.

27. Güllü S, Şahin S. Antrenörlerin intikam (öç alma) davranışlarının bazı değişkenler açısından incelenmesi. Uluslararası Sosyal Araştırmalar Dergisi. 2016; 9(47): 863-871.

28. Yıldırım A, Ünal A, Çelik M. Öğretmen kavramına ilişkin öğretmen, yönetici ve müfettiş algılarının analizi. Uluslararası İnsan Bilimleri Dergisi, 2011; 8(2), 92-109.

29. Yılmaz A, Esentürk OK, Tekkurşun-Demir G, İlhan EL. Metaphoric perception of gifted students about physical 
education course and physical education teachers. Journal of Educational and Learning, 2017; 6(2), 2017.

30. Demirtaş H, Çoban D. Üniversite öğrencilerinin öğretim elemanlarına ilişkin metaforları. Kastamonu Eğitim Dergisi, 2014; 22(3), 1279-1300.

31. Bahar-Güner, Ö, Tunca N, Alkın-Şahin S, Oğuz A. Öğretmen adaylarının öğretmen eğitimcisine ilişkin metaforik algıları. Pegem Eğitim ve Öğretim Dergisi, 2015; 5(4), 419-444.

32. Schreglmann S, Kazancı Z. Öğretmen adaylarının "yaratıcı öğretmen" kavramına yönelik metaforik algıları. Üstün Zekalılar Eğitimi ve Yaratıcılık Dergisi, 2016; 3(3), 21-34. 